\title{
Was the tail bud the ancestral centre where the fin developmental program evolved in chordates?
}

\author{
Darko D. Cotoras ${ }^{1,2,3}$, Miguel L. Allende ${ }^{1}$ \\ ${ }^{1}$ FONDAP Center for Genome Regulation, Facultad de Ciencias, Universidad de Chile, Casilla 653, Santiago, Chile \\ ${ }^{2}$ Department of Integrative Biology, University of California, Berkeley, CA 94720, USA \\ ${ }^{3}$ E-mail: darkocotoras@gmail.com
}

Key words: Archipterygium hypothesis, co-option, fin fold hypothesis, limb bud

\begin{abstract}
The structural origin of the vertebrates' paired limbs is still an unsolved problem. Historically, two hypotheses have been raised to explain the origin of vertebrate limbs: the Archipterygium Hypothesis and the Fin Fold Hypothesis. Current knowledge provides support for both ideas. In the recent years, it has been also suggested that (1) all appendages correspond to body axis duplications and (2) they are originated by the ventralization of the developmental program present in the median fins. The tail bud is also a relevant structure in the attempt to understand the origin of the vertebrates' limbs. Due to their similarities in gene expression and general organization, both structures should be studied more closely to understand their potential evolutionary link. Interestingly, in non-vertebrate chordates such as Amphioxus, it is possible to find a tail fin that during development expresses several genes that are conserved with other vertebrates' limbs and tails. This shared gene expression could be considered as an evidence of potential co-option of the same genetic tool kit from the tail to the extremities. This observation is congruent with the hypothesis of Axis paramorphism, which previously suggested similarities between the tail and limb buds.
\end{abstract}

\section{Contents}

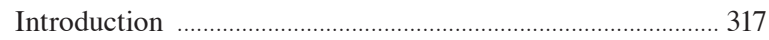

The Archipterygium hypothesis ………………………...... 318

Fin fold hypothesis .............................................................. 319

Hox genes and axis paramorphism …………........................ 320

The tail bud …….................................................................. 320

Similarities between the tail and the extremities ................. 321

Importance of retinoic acid in the development

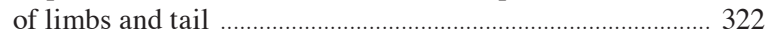

Tail similarities between vertebrate and

non-vertebrate chordates ........................................................ 323

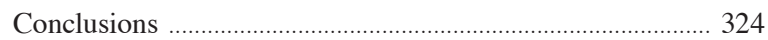

Acknowledgements ..................................................................... 324

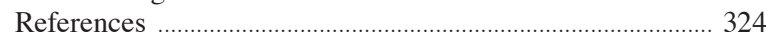

\section{Introduction}

The structural origin of the vertebrates' paired limbs is still an unsolved problem. In the 19th century, mor- phologists proposed two explanations for the origin of the limbs/fins: The 'Archipterygium Hypothesis' and the 'Fin Fold Hypothesis' (both reviewed by Cole and Currie, 2007). Later, it was suggested that the extremities were related with side folds in the Cambrian vertebrates Myllokunmingia and Haikouichthys. This has been rejected due to lack of evidence of a skeletal and muscular support, which are the distinctive features of true limbs (Coates, 2003).

The oldest known paired fin-like appendages were present in the jawless Thelodonta, however it is not obvious they had an endoskeletal support (Coates and Cohn, 1998) and their homology to gnathostome paired fins is uncertain. The first unquestioned pectoral fins possessing an internal skeleton arise later in the Osteostraci and Pituriapsida (Janvier, 2008). While the pelvic fins are first observed in the jawed Placoderms. They are considered a case of serial homology with respect to the pectoral ones (Coates, 2003).

The paleontological and anatomical evidence do not provide a definitive answer to uncover which is the ancestral structure of vertebrates' extremities. However, the analysis of genes involved on fins/limbs development as well as the detailed developmental mechanisms could provide new data to evaluate old and new hypotheses.

In conjunction to the 'Archipterygium hypothesis' (Fig. 1, right side), 'Fin fold hypothesis' (Fig. 1, centre) and new ideas related with Hox gene patterning, we will examine the tail bud as a structure from which potentially the developmental mechanism for the appendage development was co-opted. This idea builds up on previously suggested similarities between the tail and limb buds (Grüneberg, 1956; Freitas et al., 2006) and the hypothesis of Axis paramorphism (Minelli, 2000, 2003).

The aim of this study is to examine gene expression and developmental data in order to evaluate which of the proposed hypothesis about the origin of vertebrates' extremities is better supported. On this paper 


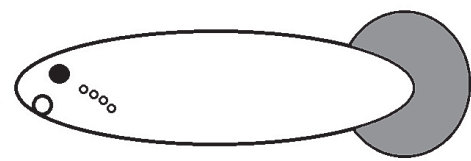

Tail Bud Hypothesis

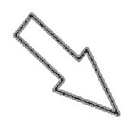

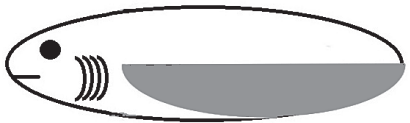

Lateral Fin Fold Hypothesis
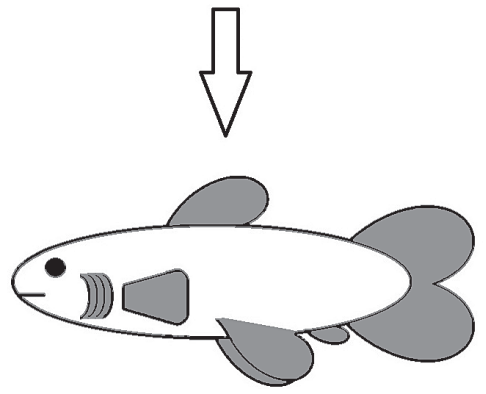

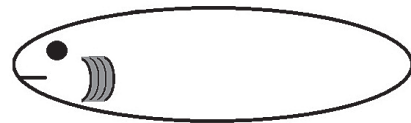

Archipterygium Hypothesis

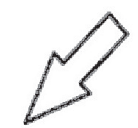

Fig. 1. Traditionally there have been suggested two alternatives as potential ancestral structures to vertebrates' extremities: continuous lateral fin folds (centre; Lateral Fin Fold Hypothesis) or branchial gills (right; Archipterygium Hypothesis). We propose that the same genes involved on tail fin development could later have been co-opted in other fins (left; Tail Bud Hypothesis). It is also possible to postulate another scenario where the genetic tool kit moves from the branchial gills to the ribbon fin or from the tail fin into the branchial gills.

we show that the shared gene expression through development between tail bud and extremities could be considered as an evidence of potential co-option of the same genetic tool kit. The fact that the tail appears in the fossil record before any kinds of fins or limbs, opens to the possibility of the tail bud as the ancestral structure where this genetic mechanism first appeared.

\section{The Archipterygium hypothesis}

In the middle of $19^{\text {th }}$ century, Carl Gegenbaur (1876, 1878) proposed that the limbs might be derived from the gill arches based on observations in Chondrichthyes' fins and in the archipterygial fins found in the Australian lungfish Neoceratodus forsteri (Krefft, 1870) (Kardong, 2012). He proposed that the archipterygial axis present in the fins corresponds to the extended gill radial and its gill arch would give rise to the pectoral girdle. It has also been reported that during the breeding season the male pelvic fin of Lepidosiren paradoxa (Fitzinger, 1837), also a lungfish, becomes a gill-like organ (reviewed by Foxon, 1933). Despite this being a seasonal change, it may reveal a developmental relationship between those structures.

Many genes are expressed in both gill arches and limbs in tetrapods. O'Rourke and Tam (2002) published an extensive review of the genes expressed in limb and branchial arch in the mouse. There are a numerous genes expressed in both organs belonging to different signaling pathways such as Fgf ( $f g f 4, f g f 8$, $f g f 9, f g f 10$ and $f g f r 2)$, Shh (shh, gli1, gli2, gli3 and patch), Wnt (wnt5a and wnt1l) and Bmp (bmp2, bmp4 and $b m p 7$ ). In addition, there is a long list of shared transcription factors, which include: twist, $d l x 1, d l \times 2$, dlx3, dlx5, dlx6, msxl, msx2, alk3, alk4, cart1, pitxl, gsc and $m t s h$.

Other examples are $R$ - $f n g, b m p 2$ and $f g f 4$, which are expressed in the ectoderm of the gill arch and in the apical ectodermal ridge (AER) of the limb (Tabin et al., 1999). The gene goosecoid ( $g s c$ ) is expressed in the mesenchyme of both structures. Sonic hedgehog $(s h h)$, on the other hand, is expressed in the ectoderm of the branchial arch and in both the mesenchyme and ectoderm of the limb (Bouldin et al., 2010). Additional interesting cases are $d l x l$ and $d l x 2$, these genes are expressed in the mesenchyme of the branchial arch and in the AER of the limb (Tabin et al., 1999).

Studies in the little skate Leucoraja erinacea (Mitchill, 1825) (Gillis et al., 2009), verified that gene expression patterns typical of the limb are found in the gill arches. $s h$ is expressed in the epithelium covering the gill arch and its receptor $p t c 2$ is expressed in the underlying mesenchyme. Meanwhile, $f g f 8$ is expressed in the posterior region of the epithelium and has a regulatory feedback with $s h h$. These patterns bear simi- 
larity with the expression of these genes during limb development. Furthermore, the exogenous application of retinoic acid (RA) or shh generates mirror duplication on the gill arch skeleton as it happens in the extremities. On the other hand, the gill arch of the ray has a ridge of pseudostratified epithelium, which closely resembles the AER of limb buds.

Shared gene expression between gill arches and developing extremities in different vertebrates supports the anatomical based hypothesis of Gegenbaur. However, a more systematic survey across different developmental pathways and vertebrate species is required.

\section{Fin fold hypothesis}

Francis M. Balfour (1881) and J.K. Thacher (1877) independently developed the Fin Fold Hypothesis; it says that paired fins evolved from ribbon-like fins, which extended along the sides of basal vertebrates. This idea correlates with the observations in early vertebrates (e.g. Myllokunmingia and Haikouichthys; Coates, 2003), as well as the presence of metapleural folds on the sides of the body of amphioxus (Branchiostoma floridae (Pallas, 1774); Brusca and Brusca, 2003). However, conceptually it is problematic because there is no evidence, which supports the existence of muscle and endoskeleton, so they are not considered true appendages.

During the larval stages of development in many fish species it is possible to recognize a single continuous median fin, which, later partially degenerates and forms the median fins (Mabee et al., 2002). It does not match the structure suggested by the Fin Fold hypothesis, but demonstrates a link between a continuous fin and median fins. In fact, the positional symmetry between the dorsal and anal fin has been interpreted as a modular system, which ancestrally could have been a single structure (Nelson, 1984; Mabee et al., 2002).

In zebrafish, Danio rerio (Hamilton-Buchanan, 1822), the median fin grows starting at 16 hours post fertilization (hpf), from caudal towards anterior. Its growth is accompanied by the expression of $d l x 5 a$ and $s p 9$, both gene families are also expressed in the pectoral fins (Abe et al., 2007). At $30 \mathrm{hpf}$ the expression of $m s x a, m s x b, m s x d$ and $m s x c$ can be found along the whole fold (Akimenko et al., 1995). All of these $m s x$ genes, except $m s x c$, are expressed in the ectodermal and mesodermal portion of the median fin fold and in the pectoral fin bud. Msxc appears only in the mesodermal tissue (Akimenko et al., 1995). Additionally, expression of the adhesion protein Laminin $\alpha 5$ has been found in pectoral fins as well as in the median fin fold (Webb et al., 2007).

Studies in chondrichthyes have also demonstrated gene expression shared between unpaired (median) and paired fins (Freitas et al., 2006). These comparisons are also valid between other vertebrate species. For example, the median fins of the small spotted catshark, Scyliorhinus canicula (Linnaeus, 1758), express Hoxd (hoxd9, hoxd10, hoxd12 and hoxd13) and tbx18 genes. All of the Hoxd genes are also expressed in different stages of development in chicken limbs (Nelson et al., 1996), while tbx18 is expressed in the forelimbs and somites of chicken (Tanaka and Tickle, 2004).

Perhaps the most compelling line of evidence supporting this hypothesis is the existence of lateral bands of ectoderm competent for AER induction. They correspond to territories that exposed to certain stimuli, such as the presence of $f g f 10$ or $f g f 7$, produce an ectopic AER and limb. In the chicken three bands of competent ectoderm have been reported: one in the dorsal midline of the body from neck to tail, while the other two are on the flanks between the anterior and posterior limbs. Induction of ectopic limbs is restricted to a particular time window (Tamura et al., 2001). Something similar has been found in newts (Balinsky, 1933). An extreme case corresponds to the common skate (Raja kenojei (Müller and Henle, 1841)) where a continuous band of $m s x l$ suggests that its pectoral fins use the whole lateral stripe of competence (Yonei-Tamura et al., 2008).

Because of all these gene expression and anatomical evidence, the median fin fold has been considered as a possible ancestral fin (Cole and Currie, 2007). However, explicit mechanism of how a single median fin fold duplicated to create the paired fins is not fully clear. An alternative explanation corresponds to the ventralization of the developmental program present in the median fins into the formation of the lateral fins which would have happen through the differentiation of the lateral plate mesoderm (Freitas et al., 2014). As a requirement for the fin formation it seems necessary the ventralization of the expression field of Engrailed-1, which has a most dorsal limit at the lateral plate mesoderm in gnathostomes (Tanaka and Onimaru, 2012). Then, the evolutionary transition between median fins and paired fins occurred within the somitic mesoderm (Freitas et al., 2014). 


\section{Hox genes and axis paramorphism}

Another important insight about the origin of limbs is based on the observation that they are placed in the transition zones between different kinds of vertebrae: forelimb in the cervical-thoracic transition and hindlimbs in the dorso-sacral transition (Mabee et al., 2002). Coates and Cohn (1999) argue that these domains could have evolved in relationship to the regionalization of the gastrointestinal tract by Hox genes. Later Tanaka and Onimaru (2012) proposed a more comprehensive model where not only an anteroposterior patterning, related with Hox genes, is required for the origin of paired fins. They also included the need of dorsoventral differentiation, subdivision of somitic and splanchnic mesoderm and different initiation signals (as $T b \times 4 / 5)$.

Independently, Minelli (2000, 2003) pointed out the similarity between limbs and the main body axis due to the presence of sexually dimorphic traits on both structures. Another similitude corresponds to the fact that, all appendages develop from 'buds' devoid of endoderm. Examples from vertebrates include the tail and the paired fins, as well as the fleshy posterior dorsal and anal fins of Latimeria, which are considered to be median fins homeotically changed into a paired fin identity (Tabin and Laufer, 1993).

Which of all the appendages is the ancestral vertebrate appendage? The tail bud is present in all vertebrates, even before the origin of the extremities. Actually, the oldest fin known is the caudal fin of the Burgess Shale fossil Pikaia gracilens (Walcott, 1911) (Morris and Caron, 2012). Therefore, we argue that it is possible that much of the developmental pathway involved in the formation of this type of fins may have been co-opted later in evolution, for the development of paired appendages.

\section{The tail bud}

The tail bud can be defined 'as the caudal region of the embryonic axis immediately distal to the posterior neuropore' (Hall, 2000). Its development has been studied since the 1920's, but not without debate. A good understanding of the formation of this structure is essential in order to compare it on an evolutionary context with respect to other extremities.

Walther Vogt (1926) suggested that tail development differentiates directly from primary germ layers established during gastrulation, without a new organi- zation centre (as the Zone of Polarizing Activity (ZPA) in limb development). Meanwhile, Holmdahl (1925) suggested that the tail develops from the terminal area (for references see Handrigan, 2003) called the ventral ectodermal ridge (VER). The tail bud and VER replace the Hensen's node through an epithelial-mesenchymal transition that happens during the early stages of tail development. This phenomenon has been described for chicken and mice (Ohta et al., 2007).

On the other hand, traditionally it has been suggested that the tail of Xenopus develops directly from primary germ layers, however in recent years it has been considered that this would be a derived condition and not widespread among vertebrates (Hall, 2000). The overall development of the tail in lampreys, zebrafish, frogs, chickens and mice to some degree combines the ideas of Vogt and Holmdahl, because they mix development directly from primary germ layers

Table 1. Summary of genes expressed on fin/extremities and caudal fin/tail. *Indirect evidence (for details see on section: Similarities between the tail and the extremities). In bold, genes expressed consistently in all the discussed structures.

\begin{tabular}{|c|c|c|c|c|}
\hline \multirow[t]{2}{*}{ Gene } & \multicolumn{2}{|c|}{ Teleost } & \multicolumn{2}{|l|}{ Tetrapod } \\
\hline & Fin & $\begin{array}{l}\text { Caudal fin } \\
\text { and tail bud }\end{array}$ & Extremities & $\begin{array}{l}\text { Tail and } \\
\text { tail bud }\end{array}$ \\
\hline $\operatorname{shh}$ & $\mathrm{x}$ & $\mathrm{x}$ & $\mathrm{x}$ & \\
\hline ptc & & $\mathrm{x}$ & $\mathrm{x}$ & \\
\hline bmp $2 / 4$ & $\mathbf{x}$ & $\mathbf{x}$ & $\mathbf{x}$ & $\mathbf{x}$ \\
\hline bmp11 & & & $\mathrm{x}$ & $\mathrm{x}$ \\
\hline wnt3a & $\mathbf{x}$ & $\mathbf{x}^{*}$ & $\mathbf{x}$ & $\mathbf{x}$ \\
\hline$w n t 5 a / b$ & $\mathrm{x}$ & & $\mathrm{x}$ & $\mathrm{x}$ \\
\hline wnt11 & & $\mathrm{X}$ & $\mathrm{x}$ & $\mathrm{x}$ \\
\hline lef1 & & & $\mathrm{x}$ & $\mathrm{x}$ \\
\hline$f g f 4 / 8 / 9$ & & & $\mathrm{x}$ & $\mathrm{x}$ \\
\hline fgflo & $\mathrm{x}$ & $\mathrm{x}$ & & \\
\hline fgfl7 & & & $\mathrm{X}$ & $\mathrm{X}$ \\
\hline fgf 20 & & & & $\mathrm{x}$ \\
\hline$f g f 24$ & $\mathrm{x}$ & $\mathrm{x}$ & & \\
\hline spryl/4 & & & $\mathrm{X}$ & $\mathrm{x}$ \\
\hline spry 2 & $\mathrm{x}$ & & $\mathrm{x}$ & $\mathrm{x}$ \\
\hline$m s x A / C / D$ & $\mathrm{x}$ & $\mathrm{X}$ & & \\
\hline $\operatorname{msx} B$ & $\mathbf{x}$ & $\mathbf{x}$ & $\mathbf{x}$ & $\mathbf{x}$ \\
\hline$t b \times 2 / 5$ & & & $\mathrm{x}$ & $\mathrm{x}$ \\
\hline $\begin{array}{l}\text { hoxal } 3 b \text {, } \\
\text { hoxc } 6 a \text {, } \\
\text { hoxd12a } \\
\text { hoxc } 8 \text { a and } \\
\text { hoxd13 }\end{array}$ & $\mathrm{x}$ & $\mathrm{x}$ & & \\
\hline hoxb10/13 & & & $\mathrm{x}$ & $\mathrm{x}$ \\
\hline hoxd11/13 & & & $\mathrm{x}$ & $\mathrm{x}$ \\
\hline
\end{tabular}


and secondary development from some kind of organization center (Handrigan, 2003).

\section{Similarities between the tail and the extremities}

The idea that limb and tail buds present similar development was first mentioned by Hans Grüneberg (1956) and later suggested again by other authors (Schubert $e t$ al., 2000). At the same time it also matches the idea of Axis paramorphism as long as the tail is considered as an appendage itself.

Histologically the VER and the AER correspond to an ectodermal epithelial tissue that covers proliferative mesenchyme. In both cases the epithelium/mesenchyme interaction is important for the proliferation of mesodermal cells (Ohta et al., 2007).

In zebrafish there is a 'tail organizer', in the sense of been the source of signaling pathway components such as Wnt, Bmp and Nodal (Liu et al., 2004), in a similar way that the ZPA is a source of Shh in the tetrapod limb bud (Bouldin et al., 2010). Additionally, in mouse, a mutation in the gene stratifin produces the phenotype called repeated epilation in which the VER and the AER are very thin and there is an abnormal development of both limbs and tail (Salzgeber and Guénet, 1984; Herron et al., 2005).

Concerning the development of limbs, the Shh pathway has been studied extensively and it is associated with the antero-posterior polarization processes (Bouldin et al., 2010). The presence of Shh was detected in the posterior regions of tetrapod limbs (Riddle et al., 1994), teleost fish (Reifers et al., 1998), the little skate (L. erinacea) and sharks (Chiloscyllum punctatum (Müller and Henle, 1838) and S. canicula) (Hadzhiev et al., 2007; Sakamoto et al., 2009) (Table 1). The caudal fin of zebrafish expresses transcripts of several genes (e.g.ptc and shh) present in the Shh signaling pathway (Krauss et al., 1993; Hadzhiev et al., 2007). In mouse there is expression in the caudal region, however it is in the future spinal cord area (Solloway and Robertson, 1999). As this expression occurs later in development (day 9.5) it is probably not related with the formation of the tail itself.

Elements from the Bmp pathway are expressed recurrently in both structures (Table 1). For example, Bmp2 is expressed in the chicken AER (Akita et al., 1996), the mouse limb bud (Moon et al., 2000) and the zebrafish pectoral fin (Neumann et al., 1999). It is also present in the mouse VER from the earliest stages until the growth of the tail finishes. Another gene from this pathway is $b m p 4$, in mouse it is present in the AER (Akita et al., 1996), but not in the VER (Catala et al., 1996). In addition, many BMPs have been detected in the caudal fin primordium of zebrafish (Hadzhiev et al., 2007). A final example is Bmp11, which is present in the tail bud and also in the limb bud of Xenopus (Gamer et al., 1999).

Several proteins of the Wnt pathway are found in vertebrate limbs and tails (Table 1). Wnt3a is expressed in mice limbs (Visel et al., 2004), as well as the most caudal portion of the tail bud (Takada et al., 1994). Mice carrying null alleles for wnt 3 have truncated tail bud development, but there was no major effect on the extremities (Greco et al., 1996). It could suggest the expression of other genes with redundant functions or the fact that wnt 3 is actually involved in other developmental processes on the limb. For chicken wnt $3 a$ has been reported in the AER (Kengaku et al., 1998). In zebrafish, Wnt3a is expressed in the AER (Ng et al., 2002) and morpholino knockdowns of wnt8 and wnt $3 a$ completely blocked the formation of the tail (Thorpe et al., 2005). Consistent with this phenotype, wnt 8 expression is detected at the tip of the tail in zebrafish (Kelly et al., 1995). Moreover, the exogenous application of Wnt8c on the flank of chicken embryos induces the formation of an ectopic limb (Kawakami et al., 2001).

$W n t 5 a$ and $w n t 5 b$ are also expressed in the chicken AER (Loganathan et al., 2005). The first one has a role related with the growth of the underlying mesenchyme (Dealy et al., 1993). The same gene is expressed in the pectoral fins of medaka, Oryzias latipes (Temminck and Schlegel, 1846) (Yokoi et al., 2003). In mouse, wnt5a is involved in the proliferation of branchial arches, facial protrusions, limb bud, VER (Goldman et al., 2000), fingers and genitals. In the mutant wnt5a-/- many of these tissues, including the tail and limbs, present a truncation in their growth (Yamaguchi et al., 1999). The expression of this gene in the branchial arches could also be considered as an argument in favor of the Archipterygium Hypothesis. In addition, wnt $5 b$ has a pattern of expression in the tail that is very similar to the one observed for wnt3a (Takada et al., 1994). On the other hand, during the regeneration process of the Xenopus tadpole tail, it is possible to detect the expression of $w n t 3 a$ and $w n t 5 a$ (Lin and Slack, 2008).

Another example is wnt11, which is expressed in the tail bud of zebrafish (Makita et al., 1998), chicken (Tanda et al., 1995) and Xenopus (Ku and Melton, 1993), as well as in the limbs of chicken (Tanda et al., 1995) and mouse (Christiansen et al., 1995). Finally, the effector of the Wnt pathway, Lefl, is expressed in 
the mouse limbs and tail (Oosterwegel et al., 1993).

A very important gene family for limb development corresponds to the Fgf genes; interestingly very few of these genes are expressed in the tail (Table 1). On mouse AER the genes $f g f 4, f g f 8, f g f 9$ and $f g f 17$ are expressed, but only the latter is present in the VER (Goldman et al., 2000). In zebrafish, fgfl0 is expressed in the pectoral fin, tail and gill arches (Thisse and Thisse, 2004). Another gene in this family, $f g f 24$, is expressed in the mesenchyme of the pectoral fin (Draper et al., 2003) and in the tail bud of zebrafish (Abe et al., 2007). No orthologues were found for this gene in tetrapods, but it is present in Chondrichthyes (Draper et al., 2003).

Functionally in mice, the maintenance of the AER depends only on Fgf10 (Norton et al., 2005) and there is no presence of this transcript in the VER (Goldman et al., 2000). The mutant mouse for this gene lacks lungs and anterior and posterior limbs (Sekine et al., 1999). Along the same line, during the regeneration process of the Xenopus tadpole tail there is expression of $f g f 8, f g f 9$, $f g f 10$ and $f g f 20$ (Lin and Slack, 2008).

The Sprouty family of proteins is antagonist of receptor tyrosine kinases, including FGF receptors. Spryl, spry2 and spry4 are expressed in the mouse extremities and in the VER (de Maximy et al., 1999; Goldman et al., 2000) (Table 1). In addition, spry2 is expressed in the zebrafish pectoral fin (Fürthauer et al., 2004).

Also, there are a number of common transcription factors between the two structures (Table 1). Several genes of the Msx family ( $m s x A, m s x B, m s x C$ and $m s x D)$ are expressed in pectoral fins and the fin fold, including the caudal fin of zebrafish (Akimenko et al., 1995). In mice, $m s x l$, functionally related to $m s x b$ in zebrafish (Akimenko et al., 1995), is expressed in the VER (Lyons et al., 1992) and AER (Tribioli et al., 2002). Other example is evxl, which is expressed in the mouse limb and the zebrafish fin (Brulfert et al., 1998), as well as in the tails of both organisms (Beck et al., 2001). Another transcription factor that is found in a wide variety of appendages is $d l l$ (Panganiban et al., 1997).

The Tbx transcription factors are also important in limb and tail development (Table 1). In chicken, $t b x 3$ is expressed in the AER and in the tail bud, among other structures (Gibson-Brown et al., 1998). In the Japanese newt, Cynops pyrrhogaster (Boie, 1826), cptbx2 is expressed in the tail and the limb (Sone et al., 1999).

The Hox genes are usually related with segmental differentiation, but they also present shared expression between tail and limbs (Table 1). In Mexican axolotls,
Ambystoma mexicanum (Shaw and Nodder, 1798), there is expression of hoxbl3 and hoxcl0 (short transcript) in the tip of the tail as well as in the hindlimb and in lower levels of the forelimbs (Carlson et al., 2001). In mice, hoxd11 (Gérard et al., 1997) and hoxd13 (Dollé et al., 1991) are expressed in the limb and tail bud. In zebrafish, the genes hoxc6a, hoxd12a (Thisse and Thisse, 2004), hoxc8a (Thisse et al., 2001), hoxd13 and hoxal3b (Thisse and Thisse, 2005) are expressed in the pectoral fin and the tail bud. Finally, in S. canicula there is also expression of hoxd in the tail fin (Freitas et al., 2006).

Ledent (2002) proposed a possible relationship between the adult caudal fin of fishes and the autopod of tetrapods. The author suggests that the Hox genes could be responsible for the axis bending which causes the heterocercal condition in fishes in the same way as they are responsible for the proximodistal finger specification of the tetrapod limb. In this scenario, Hox genes would have been recruited secondarily for limb development.

All these similarities between the genetic mechanism involved in limb and tail formation are also congruent with the Axis paramorphism idea (Minelli, 2000, 2003). On this conceptual framework, both structures could be considered as repetitions of the main body axis. Note that the tail is also a structure that presents sexual dimorphism. It has been documented on the tail length of birds (Winquist and Lemon, 1994) and snakes (King, 1989); number of vertebrae in salamanders (Ficetola et al., 2013); and colours on birds (Dakin and Montgomerie, 2013) and fish (Godin and McDonough, 2003).

While it is often possible to identify mutations with a limb phenotype having no consequence in the tail or vice versa, this could be explained by the existence of functional redundancies in one of the tissues.

\section{Importance of retinoic acid in the development of limbs and tail}

Retinoic acid (RA) is a regulator of the Shh pathway (Dahn et al., 2007). In zebrafish, it is secreted from the somites into the lateral plate mesoderm starting with fin development (Neto et al., 2012). Experiments of exogenous application generate mirror duplications of the tetrapod limb (Tabin, 1995). In zebrafish and mummichog (Fundulus heteroclitus (Linnaeus, 1766)), the exposure to exogenous RA during gastrulation produces multiple pectoral fins. The same effect with 
shortening of the tail and deletion of brain and craniofacial structures is observed when the treatment is at $50 \%$ of epiboly (Vandersea et al., 1998). If the tail were related evolutionarily and/or mechanistically to the development of the limbs it would be expected that similar effects would result from the same stimulus.

In nature and under breeding conditions spontaneous cases of tail duplication in fish have been reported. The explanation for this phenotype is not always clear or unambiguous, though among the possible causes genetic factors and/or the effect of RA pathway interference are mentioned. For example, in cultured gilthead sea bream, Sparus aurata (Linnaeus, 1758), it has been reported the presence of osteological malformations in the tail fin. Among them, it is the formation of a second hypoplastic fin in the dorsal region of the main caudal fin. Environmental contaminants have been mentioned as potential causes, as they are known to alter the expression of homeotic genes in turn regulated by RA (Koumoundouros et al., 1997).

On the other hand, for centuries in China different varieties of goldfish have been cultivated, Carassius auratus (Linnaeus, 1758), some of which have double caudal fins. The experimental removal of yolk material of double caudal fin goldfish produces an adult with a single caudal fin (Nan'er, 1989). A similar result was found by treating the eggs with polyethylene glycol or UV light (Nan'er, 1993). The yolk sac stores vitamin A, which is a precursor of RA (Lampert et al., 2003) thus; these treatments lead to a reduced availability of vitamin A and to a decreased synthesis of RA. It is assumed that this reduction would not be strong enough to cause other developmental abnormalities. Probably somehow double-tailed varieties have managed to accumulate higher concentrations of vitamin $\mathrm{A}$ in the yolk. By removing this excess, the animal reverts to the ancestral condition.

Thus, though it has not been demonstrated, there is indirect evidence that RA could be involved in tail duplication, an intriguing parallel to what has been shown in limbs, branchial arches and radials in caudal fin regeneration (White et al., 1994).

Another suggestive link between limbs and tails is related to a documented homeotic transformation of the tail into legs in different frog species (Mahapatra et al., 2002; Mohanty-Hejmadi and Crawford, 2003). These effects were obtained after vitamin A treatment of larvae whose tails had been amputated (Mahapatra et al., 2002). The effect of vitamin A, a precursor for RA, could suggest a potential role of RA on this homeotic transformation.
In summary, functional experiments show that RA has a similar role in tail and limb development on different kinds of vertebrates, corresponding to another piece of evidence of the potential evolutionary link of these structures.

\section{Tail similarities between vertebrate and non-verte- brate chordates}

If the gene tool kit associated to the formation of the tail was co-opted into the extremities development, then it would be expected that this gene tool kit will be present on a non-vertebrate chordate possessing a tail. The tail of the cephalochordate amphioxus (B. floridae) in the early stages of development corresponds to an epithelium without mesenchymal components and the rays are groups of cilia (Flood, 1975; Crowther and Whittaker, 1994). However, after the metamorphosis abundant dermal matrix is accumulated producing a predominantly dermal tail fin (Mansfield and Holland, 2015). Then, the amphioxus tail in later stages of development is composed by mesodermal and ectodermal tissue as the one in vertebrates.

From the gene expression aspect, the amphioxus tail bud does express genes shared between the tail and limbs of vertebrates: AmphiWnt3, AmphiWnt5, AmphiWnt8, AmphiWnt11 and AmphiEvxA (ortholog of evxl) (Schubert et al., 2000, 2001; Ferrier et al., 2001; Holland, 2002). On the other hand, genes from families of the RA pathway (RAR, raldh, cyp26 and aldh) are present in its genome (Marlétaz et al., 2006) and, in fact, Aldhla is expressed caudally near the developing tail (Dalfó et al., 2002). Complementarily, Koop et al. (2011) showed that a high RA concentration induces tail regression.

The Urochordate Ciona intestinalis (Linnaeus, 1767) (Ascidiacea) on its larval stage presents a tail that retracts during the metamorphosis. It is created by cell rearrangements and not by a posterior growth zone as in vertebrates (Takatori et al., 2007). However, sequences belonging to the RA pathway such as raldh2, aldh, RAR and cyp26 have been also found in its genome (Kanda et al., 2009). In particular cyp26 (Nagatomo and Fujiwara, 2003) and adh3 (Cañestro et al., 2003) show expression in the tail bud area. Also, exposure to RA produces malformations in its tail (Nagatomo et al., 2003). Moreover, the regionalization of the tail tip epidermis occurs through Fgf signaling (Takatori et al., 2007). But, another Urochordate, Oikopleura dioica (Fol, 1872) (Appendicularia), does 


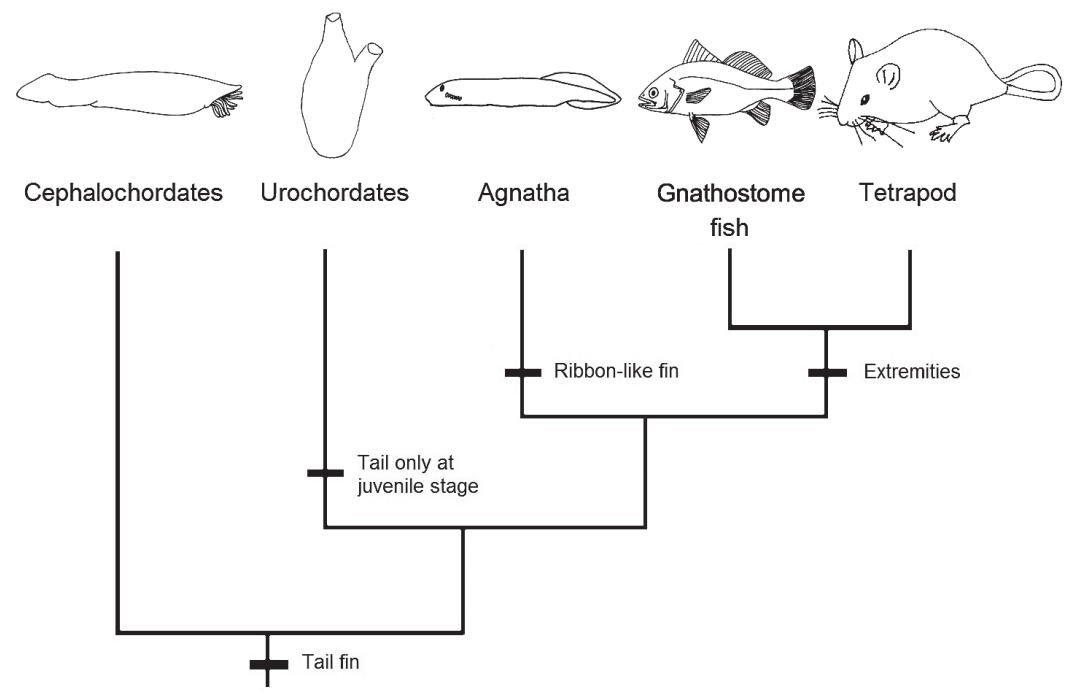

Fig. 2. Evolution of the extremities in chordates. The extremities appeared with the basal gnathostomes. Ribbonlike fins are possible to identify in agnatha and early stages of development in some fish. The tail fin appears at the base of the chordate and secondary lost in the adult stages of Urochordata. Note that the presence of tail fin is considered as a 'minimum boundary' to the estimation of existence for the tail bud. Phylogeny after Putnam et al., 2008. Animal drawings after: Ljósm, Christine Walsh and ratbehavior.org.

not have any of the RA related genes within its genome (Marlétaz et al., 2006).

The expression and presence in the genome of nonvertebrate chordates of many relevant genes in extremities/tail development, suggests that they were already required for tail development prior to the origin of vertebrates. Therefore, the mechanisms in which they are involved could have been co-opted for the formation of paired limbs (Schubert et al., 2000; Fig. 2).

\section{Conclusions}

Based on the current state of knowledge, is very difficult to assess whether the gill arch or a fin fold gave rise to the extremities (Fig. 1). Both hypotheses - the Archyptergygium and the Fin Fold Hypothesis - are partially supported by gene expression data. On the other hand, the hypothesis of the ventralization of the zones of competence could be broadly grouped with the Fin Fold Hypothesis, because in both cases the original genetic mechanism ia present in a ribbon-like fin present in the outer body of the organism. Here, as an alternative hypothesis (Fig. 1, left side), we presented evidence that similar genes are involved in the formation of the tail and the limb. Part of this evidence is the common role of RA in the duplication of limbs and tails on different lineages of vertebrates. Moreover, other genetic elements related with extremities and tail development are present in non-vertebrate chordates. This suggests that the genetic tool kit involved in tail development could have been co-opted by the extremities (Schubert et al., 2000).
This observation is congruent with the hypothesis of Axis paramorphism (Minelli, 2000, 2003). We think that further studies including gene expression analysis of the tail bud and gill arches in amphioxus and the larval tail of Ciona will help to confirm or disprove this idea.

\section{Acknowledgements}

The authors thank to Jessie Atterholt, David Lindberg and anonymous reviewers for suggestions. We also have a special recognition to Alexander Vargas for valuable discussions and insights of an earlier version of the manuscript. Finally, we thank the grant FONDAP 15090007 to MLA.

\section{References}

Abe G, Ide H, Tamura K. 2007. Function of FGF signaling in the developmental process of the median fin-foldfin fold in zebrafish. Developmental Biology 304: 355-366.

Akimenko M, Johnson SL, Westerfield M, Ekker M. 1995. Differential induction of four msx homeobox genes during fin development and regeneration in zebrafish. Development 121: 347-357.

Akita K, Francis-West P, Vargesson N. 1996. The ectodermal control in chick limb development: Wnt-7a, Shh, Bmp-2 and Bmp-4 expression and the effect of FGF-4 on gene expression. Mechanisms of Development 60: 127-137.

Balfour FM. 1881. On the development of the skeleton of the paired fins of Elasmobranchii, considered in relation to its bearing on the nature of the limbs of the vertebrata. Proceedings of the Zoological Society London 1881: 656-671.

Balinsky BI. 1933. Das Extremitatenseitenfeld seine ausdehnung und beschaffenheit. Roux's Arch. Developmental Biology 130: 704-736. 
Beck CW, Whitman M, Slack JMW. 2001. The role of BMP signaling in outgrowth and patterning of the Xenopus tail bud. Developmental Biology 238: 303-314.

Bouldin CM, Gritli-Linde A, Ahn S, Harfe BD. 2010. Shh pathway activation is present and required within the vertebrate limb bud apical ectodermal ridge for normal autopod patterning. Proceedings of the National Academy of Sciences of the United States of America 107: 5489-5494.

Brulfert A, Monnot M, Geraudie J. 1998. Expression of two Even-skipped genes eve 1 and evx2 during zebrafish fin morphogenesis and their regulation by retinoic acid. International Journal of Developmental Biology 42: 1117-1124.

Brusca RC, Brusca GJ. 2003. The Cephalochordates Pp.866 in Invertebrates. Second Edition. Sinauer Associates, Inc, Publishers. Sunderland, Massachusetts. USA

Cañestro C, Godoy L, Gonzàlez-Duarte R, Albalat R. 2003. Comparative expression analysis of Adh3 during arthropod, urochordate, cephalochordate, and vertebrate development challenges its predicted housekeeping role. Evolution \& Development 5: 157-163.

Carlson MR, Komine Y, Bryant SV, Gardiner DM. 2001. Expression of Hoxb13 and Hoxc10 in developing and regenerating axolotl limbs and tails. Developmental Biology 229: 396-406.

Catala M, Teillet MA, De Robertis EM, Le Douarin M. 1996. A spinal cord fate map in the avian embryo: while regressing, Hensen's node lays down the notochord and floor plate thus joining the spinal cord lateral walls. Development 122: 2599-2610.

Christiansen JH, Dennis CL, Wicking CA, Monkley SJ, Wilkinson DG, Wainwright BJ. 1995. Murine Wnt-11 and Wnt-12 have temporally and spatially restricted expression patterns during embryonic development. Mechanisms of Development 51: 341-350.

Coates MI, Cohn MJ. 1998. Fins, limbs, and tails: outgrowths and axial patterning in vertebrate evolution. BioEssays 20: 371-381.

Coates MI, Cohn MJ. 1999. Vertebrate axial and appendicular patterning: the early development of paired appendages. American Zoologist 39: 676-685.

Coates MI. 2003. The evolution of paired fins. Theory in Biosciences 122: 266-287.

Cole NJ, Currie PD. 2007. Insights from sharks: evolutionary and developmental models of fin development. Developmental Dynamics 236: 2421-2431.

Crowther RJ, Whittaker JR. 1994. Serial repetition of cilia pairs along the tail surface of an ascidian larva. Journal of Experimental Zoology 268: 9-16.

Dahn RD, Davis MC, Pappano WN, Shubin NH. 2007. Sonic hedgehog function in chondrichthyan fins and the evolution of appendage patterning. Nature 445: 311-314.

Dakin R. and Montgomerie R. 2013. Eye for an eyespot: how iridescent plumage ocelli influence peacock mating success. Behavioral Ecology 24: 1048-1057.

Dalfó D, Albalat R, Molotkov A, Duester G, González-Duarte R. 2002. Retinoic acid synthesis in the prevertebrate amphioxus involves retinol oxidation. Development, Genes and Evolution 212: 388-393.

de Maximy AA, Nakatake Y, Moncada S, Itoh N, Thiery JP, Bellusci S. 1999. Cloning and expression pattern of a mouse homologue of Drosophila sprouty in the mouse embryo. Mechanisms of Development 81: 213-216.
Dealy CN, Roth A, Ferrari D, Brown AM, Kosher RA. 1993. Wnt-5a and Wnt-7a are expressed in the developing chick limb bud in a manner suggesting roles in pattern formation along the proximodistal and dorsoventral axes. Mechanisms of Development 43: 175-196.

Dollé P, Izpisúa-Belmonte JC, Boncinelli E, Duboule D. 1991. The Hox-4.8 gene is localized at the 5' extremity of the Hox4 complex and is expressed in the most posterior parts of the body during development. Mechanisms of Development 36: 3-13.

Draper BW, Stock DW, Kimmel CB. 2003. Zebrafish $f g f 24$ functions with $f g f 8$ to promote posterior mesodermal development. Development 130: 4639-4654.

Ferrier DEK, Minguillón C, Cebrián C, Garcia-Fernández J. 2001. Amphioxus Evx genes: implications for the evolution of the midbrain-hindbrain boundary and the chordate tailbud. Developmental Biology 237: 270-281.

Ficetola GF, Bonardi A, Colleoni E, Padoa-Schioppa E and Scali S. 2013. Evolution of sexual dimorphism in the number of tail vertebrae in salamanders: comparing multiple hypotheses. Evolutionary Biology 40: 220-227.

Flood PR. 1975. Ciliary rootlet-fibers as tail fin-rays in larval amphioxus (Branchiostoma lanceolatum, Pallas). Journal of Ultrastructure Research 51: 218-225.

Foxon GEH. 1933. Pelvic fins of the Lepidosiren. Nature 131: 732-733.

Freitas R, Zhang GJ, Cohn MJ. 2006. Evidence that mechanisms of fin development evolved in the midline of early vertebrates. Nature 442: 1033-1037.

Freitas R, Gómez-Skarmeta JL, Rodrigues PN. 2014. New frontiers in the evolution of fin development. Journal of Experimental Zoology Part B: Molecular and Developmental Evolution. 322: 540-552.

Fürthauer M, Van Celst J, Thisse C, Thisse B. 2004. Fgf signalling controls the dorsoventral patterning of the zebrafish embryo. Development 131: 2853-2864.

Gamer LW, Wolfman NM, Celeste AJ, Hattersley G, Hewick R, Rosen V. 1999. A novel BMP expressed in developing mouse limb, spinal cord, and tail bud is a potent mesoderm inducer in Xenopus embryos. Developmental Biology 208: 222-232.

Gegenbaur C. 1876. Zur Morphologie der Gliedmaassen der Wirbelthier. Morph. Jahrb 1876, 2: 369-420

Gegenbaur C. 1878. Elements of Comparative Anatomy, Macmillan and Co., London.

Gérard M, Zákány J, Duboule D. 1997. Interspecies exchange of a Hoxd enhancer in vivo induces premature transcription and anterior shift of the sacrum. Developmental Biology 190: 32-40.

Gibson-Brown JJ, Agulnik SI, Silver LM, Papaioannou VE. 1998. Involvement of T-box genes Tbx2-Tbx5 in vertebrate limb specification and development. Development 125 : 2499-2509.

Gillis JA, Dahn RD, Shubin NH. 2009. Shared developmental mechanisms pattern the vertebrate gill arch and paired fin skeletons. Proceedings of the National Academy of Sciences of the United States of America 106: 5720-5724.

Godin J.J. and McDonough H.E. 2003. Predator preference for brightly colored males in the guppy: a viability cost for a sexually selected trait. Behavioral Ecology 14: 194-200.

Goldman DC, Martin GR, Tam PPL. 2000. Fate and function of the ventral ectodermal ridge during mouse tail development. Development 127: 2113-2123. 
Greco TL, Takada S, Newhouse MM, McMahon JA, McMahon AP, Camper SA. 1996. Analysis of the vestigial tail mutation demonstrates that Wnt-3a gene dosage regulates mouse axial development. Genes \& Development 10: 313-324.

Grüneberg H. 1956. A ventral ectodermal ridge of the tail in mouse embryos. Nature 177: 787-788.

Hadzhiev Y, Lele Z, Schindler S, Wilson SW, Ahlberg P, Strähle U, Müller F. 2007. Hedgehog signaling patterns the outgrowth of unpaired skeletal appendages in zebrafish. BMC Developmental Biology 7: 75.

Hall BK. 2000. A role for epithelial-mesenchymal interactions in tail growth/morphogenesis and chondrogenesis in embryonic mice. Cells Tissues Organs 166: 6-14.

Handrigan GR. 2003. Concordia discors: duality in the origin of the vertebrate tail. Journal of Anatomy 202: 255-67.

Herron BJ, Liddell RA, Parker A, Grant S, Kinne J, Fisher JK, Siracusa LD. 2005. A mutation in stratifin is responsible for the repeated epilation (Er) phenotype in mice. Nature Genetics 37: 1210-1212.

Holland LZ. 2002. Heads or tails? Amphioxus and the evolution of anterior-posterior patterning in deuterostomes. Developmental Biology 241: 209-228.

Janvier P. 2008. Early jawless vertebrates and cyclostome origins. Zoological Science 25: 1045-1056.

Kanda M, Wada M, Fujiwara S. 2009. Epidermal expression of Hox1 is directly activated by retinoic acid in the Ciona intestinalis embryo. Developmental Biology 335: 454-463.

Kardong KV. 2012. Origin of paired fins. Pp. 327-331 in: Vertebrates Comparative Anatomy, Function, Evolution. $6^{\text {th }}$ Edition. McGraw-Hill, New York.

Kawakami Y, Capdevila J, Büscher D, Itoh Y, Rodríguez Esteban C, Izpisuá Belmonte JC. 2001. WNT signals control FGF-dependent limb initiation and AER Induction in the chick embryo. Cell 104: 891-900.

Kelly GM, Greenstein P, Erezyilmaz DF, Moon RT. 1995. Zebrafish wnt 8 and wnt 8 b share a common activity but are involved in distinct developmental pathways. Development 121: 1787-1799.

Kengaku M, Capdevila J, Rodriguez-Esteban C, De La Peña J, Johnson RL, Izpisúa Belmonte JC, Tabin CJ. 1998. Distinct WNT pathways regulating AER formation and dorsoventral polarity in the chick limb bud. Science 280: 1274-1277.

King RB. 1989. Sexual dimorphism in snake tail length: sexual selection, natural selection, or morphological constraint? Biological Journal of the Linnean Society 38: 133-154.

Koop D, Holland LZ, Setiamarga D, Schubert M, Holland ND. 2011. Tail regression induced by elevated retinoic acid signaling in amphioxus larvae occurs by tissue remodeling, not cell death. Evolution \& Development 13: 427-435.

Krauss S, Concordet JP; and Ingham PW 1993. A functionally conserved homolog of the Drosophila segment polarity gene $\mathrm{hh}$ is expressed in tissues with polarizing activity in zebrafish embryos. Cell 75: 1431-1444.

Koumoundouros G, Gagliardi F, Divanach P, Boglione C, Cataudella S, Kentouri M. 1997. Normal and abnormal osteological development of caudal fin in Sparus aurata L. fry. Aquaculture 149: 215-226.

Ku M, Melton DA. 1993. Xwnt-11: A maternally expressed Xenopus wnt gene. Development 119: 1161-1173.

Lampert JM, Holzschuh J, Hessel S, Driever W, Vogt K, von Lintig J. 2003. Provitamin A conversion to retinal via the b,b-carotene-15,15ф-oxygenase (bcox) is essential for pattern formation and differentiation during zebrafish embryogenesis. Development 130: 2173-2186.

Ledent V. 2002. Postembryonic development of the posterior lateral line in zebrafish. Development 129: 597-604.

Lin G, Slack JMW. 2008. Requirement for Wnt and FGF signaling in Xenopus tadpole tail regeneration. Developmental Biology 316: 323-335.

Liu C, Knezevic V, Mackem S. 2004. Ventral tail bud mesenchyme is a signaling center for tail paraxial mesoderm induction. Developmental Dynamics 229: 600-606.

Loganathan PG, Nimmagadda S, Huang R, Scaal M, Christ B. 2005. Comparative analysis of the expression patterns of Wnts during chick limb development. Histochemistry and Cell Biology 123: 195-201.

Lyons GE, Houzelstein D, Sassoon D, Robert B, Buckingham ME. 1992. Multiple sites of Hox-7 expression during mouse embryogenesis: Comparison with retinoic acid receptor mRNA localization. Molecular Reproduction and Development 32: 303-314.

Mabee PM, Crotwell PL, Bird NC, Burke AC. 2002. Evolution of median fin modules in the axial skeleton of fishes. Journal of Experimental Zoology Part B: Molecular and Developmental Evolution 294: 77-90.

Mahapatra PK, Mohanty-Hejmadi P, Chainy GBN. 2002. Oxidative stress during vitamin A-induced abnormal tail regeneration in the tadpoles of Polypedates maculates. Comparative Biochemistry and Physiology Part B: Biochemistry and Molecular Biology 131: 403-410.

Makita R, Mizuno T, Koshida S, Kuroiwa A, Takeda H. 1998. Zebrafish wnt11: Pattern and regulation of the expression by the yolk cell and No tail activity. Mechanisms of Development 71: 165-176.

Marlétaz F, Holland LZ, Laudet V, Schubert M. 2006. Retinoic acid signaling and the evolution of chordates. International Journal of Biological Sciences 2: 38-47.

Mansfield JH and Holland ND. 2015. Amphioxus tails: source and fate of larval fin rays and the metamorphic transition from an ectodermal to a predominantly mesodermal tail. Acta Zoologica (Stockholm) 96: 117-125

Minelli A. 2000. Limbs and tail as evolutionarily diverging duplicates of the main body axis. Evolution \& Development 2: 157-165.

Minelli A. 2003. The origin and evolution of appendages. International Journal of Developmental Biology 47: 573-581.

Mohanty-Hejmadi P, Crawford MJ. 2003. Vitamin A, regeneration and homeotic transformation in anurans. Proceedings of the Indian National Science Academy 69: 673-690.

Moon AM, Boulet AM, Capecchi MR. 2000. Normal limb development in conditional mutants of Fgf4. Development 127: 989-996.

Morris SC, Caron J. 2012. Pikaia gracilens Walcott, a stemgroup chordate from the Middle Cambrian of British Columbia. Biological Reviews 87: 480-512.

Nagatomo K, Fujiwara S. 2003. Expression of Raldh2, Cyp26 and Hox-1 in normal and retinoic acid-treated Ciona intestinalis embryos. Gene Expression Patterns 3: 273-277.

Nagatomo K, Ishibashi T, Satou Y, Satoh N, Fijiwara S. 2003. Retinoic acid affects gene expression and morphogenesis without upregulating the retinoic acid receptor in the ascidian Ciona intestinalis. Mechanisms of Development 120: 363-372. 
Nan'er C. 1989. Studies on the formation of single caudal fin of the gold fish, Carassius auratus I. The effect of the cytoplasm on the development of caudal. Oceanologia et Limnologia Sinica 20: 453-459.

Nan'er C. 1993. Studies on the formation of single caudal fin of the gold fish, Carassius auratus III. The effect of polyethylenglicol and ultraviolet rays on the development of caudal fin. Oceanologia et Limnologia Sinica 24: 242-247.

Nelson CE, Morgan BA, Burke AC, Laufer E., DiMambro E, Murtaugh LC, Gonzales E, Tessarollo L, Parada LF, Tabin C. 1996. Analysis of Hox gene expression in the chick limb bud. Development 122: 1449-1466.

Nelson JS. 1984. Fishes of the world. New York: John Wiley \& Sons Inc.

Neto A, Mercader N, Gomez-Skarmeta JL. 2012. The Osr1 and Osr2 genes act in the pronephric anlage downstream of retinoic acid signaling and upstream of Wnt2b to maintain pectoral fin development. Development 139: 301-311.

Neumann CJ, Grandel H, Gaffield W, Schulte-Merker S, Nüsslein-Volhard C. 1999. Transient establishment of anteroposterior polarity in the zebrafish pectoral fin bud in the absence of sonic hedgehog activity. Development 126: 48174826.

Ng JK, Kawakami Y, Büscher D, Raya A, Itoh T, Koth CM, Rodríguez-Esteban C, Rodríguez-León J, Garrity DM, Fishman MC, Izpisúa Belmonte JC. 2002. The limb identity gene Tbx 5 promotes limb initiation by interacting with Wnt2b and Fgf10. Development 129: 5161-5170.

Norton WH, Ledin J, Grandel H, Neumann CJ. 2005. HSPG synthesis by zebrafish Ext 2 and Extl3 is required for Fgf10 signalling during limb development. Development 132: 4963-4973.

O’Rourke MP, Tam PPL. 2002. Twist functions in mouse development. International Journal of Developmental Biology 46: 401-413.

Ohta S, Suzuki K, Tachibana K, Tanaka H, Yamada G. 2007. Cessation of gastrulation is mediated by suppression of epithelial-mesenchymal transition at the ventral ectodermal ridge. Development 134: 4315-4324.

Oosterwegel M, van de Wetering M, Timmerman J, Kruisbeek A, Destree O, Meijlink F, Clevers H. 1993. Differential expression of the HMG box factors TCF-1 and LEF-1 during murine embryogenesis. Development 118: 439-448.

Panganiban G, Irvine SM, Lowe C, Roehl H, Corley LS, Sherbon B, Grenier JK, Fallon JF, Kimble J, Walker M, Wray GA, Swalla BJ, Martindale MQ, Carroll SB. 1997. The origin and evolution of animal appendages. Proceedings of the National Academy of Sciences of the United States of America 94: 5162-5166.

Putnam NH, Butts T, Ferrier DEK, Furlong RF, Hellsten U, Kawashima T, Robinson-Rechavi M, Shoguchi E, Terry A, Yu J, Benito-Gutiérrez E, Dubchak I, Garcia-Fernàndez J, Gibson-Brown JJ, Grigoriev IV, Horton AC, de Jong PJ, Jurka J, Kapitonov VV, Kohara Y, Kuroki Y, Lindquist E, Lucas S, Osoegawa K, Pennacchio LA, Salamov AA, Satou Y, Sauka-Spengler T, Schmutz J, Shin-I T, Toyoda A, BronnerFraser M, Fujiyama A, Holland LZ, Holland PWH, Satoh N, Rokhsar DS. 2008. The amphioxus genome and the evolution of the chordate karyotype. Nature 453: 1064-1071.

Reifers F, Böhli H, Walsh EC, Crossley PH, Stainier DYR, Brand M. 1998. Fgf8 is mutated in zebrafish acerebellar (ace) mutants and is required for maintenance of midbrainhindbrain boundary development and somitogenesis. Development 125: 2381-2395.

Riddle RD, Johnson RL, Laufer E, Tabin C. 1994. Sonic hedgehog mediates the polarizing activity of the ZPA. Cell 75: 1401-1416.

Sakamoto K, Onimaru K, Munakata K, Suda N, Tamura M, Ochi H, Tanaka M. 2009. Heterochronic shift in Hox-mediated activation of sonic hedgehog leads to morphological changes during fin development. PLoS One 4: e5121.

Salzgeber B, Guénet J-L. 1984. Studies on 'repeated epilation' mouse mutant embryos. II. Development of limb, tail, and skin defects. Journal of Craniofacial Genetics and Developmental Biology 4: 95-114.

Schubert M, Holland LZ, Holland ND. 2000. Characterization of an Amphioxus Wnt Gene, AmphiWnt11, with possible roles in myogenesis and tail outgrowth. Genesis 27: 1-5.

Schubert M, Holland LZ, Stokes MD, Holland ND. 2001. Three Amphioxus Wnt Genes (AmphiWnt3, AmphiWnt5, and AmphiWnt6) associated with the tail bud: the evolution of somitogenesis in chordates. Developmental Biology 240: 262-273.

Sekine K, Ohuchi H, Fujiwara M, Yamasaki M, Yoshizawa T, Sato T, Yagishita N, Matsui D, Koga Y, Itoh N, Kato S. 1999. Fgf10 is essential for limb and lung formation. Nature Genetics 21: 138-141.

Solloway MJ and Robertson EJ. 1999. Early embryonic lethality in Bmp5;Bmp7 double mutant mice suggests functional redundancy within the $60 \mathrm{~A}$ subgroup. Development 126 : 1753-1768.

Sone K, Takahashi TC, Takabatake Y, Takeshima K, Takabatake T. 1999. Expression of five novel T-box genes and brachyury during embryogenesis, and in developing and regenerating limbs and tails of newts. Development, Growth and Differentiation 41: 321-333.

Tabin C, Laufer E. 1993. Hox genes and serial homology. $\mathrm{Na}$ ture 361: 692-693.

Tabin C. 1995. The initation of the limb bud: Growth factors Hox genes and retinoids. Cell 80: 671-674.

Tabin C., Carroll SB, Panganiban G. 1999. Out on a limb: parallels in vertebrate and invertebrate limb Patterning and the origin of appendages. American Zoologist 39: 650-663.

Takada S, Stark KL, Shea MJ, Vassileva G, McMahon JA, McMahon AP. 1994. Wnt-3a regulates somite and tailbud formation in the mouse embryo. Genes and Development 8: 174-189.

Takatori N, Wada S, Saiga H. 2007. Regionalization of the tailtip epidermis requires inductive influence from vegetal cells and FGF signaling in the development of an ascidian, Halocynthia roretzi. Zoological Science 24: 441-448.

Tamura K, Kuraishi R, Saito D, Masaki H, Ide H, Yonei-Tamura S. 2001. Evolutionary aspects of positioning and identification of vertebrate limbs. Journal of Anatomy 199: 195-204.

Tanaka M, Onimaru K. 2012. Acquisition of the paired fins: a view from the sequential evolution of the lateral plate mesoderm. Evolution \& Development 14: 412-420.

Tanaka M, Tickle C. 2004. Tbx 18 and boundary formation in chick somite and wing development. Developmental Biology 268: 470-480.

Tanda N, Ohuchi H, Yoshioka H, Noji S, Nohno T. 1995. A chicken Wnt gene, Wnt-11, is involved in dermal development. 
Biochemical and Biophysical Research Communications 211: 123-129.

Thacher JK. 1877. Median and paired fins, a contribution to the history of vertebrate limbs. Transactions of the Connecticut Academy of Arts and Sciences 3: 281-310.

Thisse B, Pflumio S, Fürthauer M, Loppin B, Heyer V, Degrave A, Woehl R, Lux A, Steffan T, Charbonnier XQ, Thisse C. 2001. Expression of the zebrafish genome during embryogenesis (NIH R01 RR15402). ZFIN Direct Data Submission (http://zfin.org)

Thisse B, Thisse C. 2004. Fast Release Clones: A High Throughput Expression Analysis. ZFIN Direct Data Submission (http://zfin.org)

Thisse C, Thisse B. 2005. High Throughput Expression Analysis of ZF-Models Consortium Clones. ZFIN Direct Data Submission (http://zfin.org)

Thorpe CJ, Weidinger G, Moon RT. 2005. Wnt/ $\beta$-catenin regulation of the Sp1-related transcription factor sp51 promotes tail development in zebrafish. Development 132: 1763-1772.

Tribioli C, Robledo RF, Lufkin T. 2002. The murine fork head gene Foxn2 is expressed in craniofacial, limb, CNS and somitic tissues during embryogenesis. Mechanisms of Development 118: 161-163.

Vandersea MW, Fleming P, McCarthy RA, Smith DG. 1998. Fin duplications and deletions induced by disruption of retinoic acid signaling. Development, Genes and Evolution 208: 61-68.

Visel A, Thaller C, Eichele G. 2004. GenePaint.org: an atlas of gene expression patterns in the mouse embryo. Nucleic Acids Research 32: 552-556.
Vogt W. 1926. Ueber Wachstum und Gestaltungsbewegungen am hinteren Körperende der Amphibien. Anatomischer Anzeiger 61: 62-75.

White JA, Boffa MB, Jones B, Petkovich M. 1994. A zebrafish retinoic acid receptor expressed in the regenerating caudal fin. Development 120: 1861-1872.

Webb AE, Sanderford J, Frank D, Talbot WS, Driever W, Kimelman D. 2007. Laminin $\alpha 5$ is essential for the formation of the zebrafish fins. Developmental Biology 311: 369-382.

Winquist T. and Lemon R.E. 1994. Sexual Selection and Exaggerated Male Tail Length in Birds. The American Naturalist 143: 95-116.

Yamaguchi TP, Bradley A, McMahon AP, Jones S. 1999. A Wnt5a pathway underlies outgrowth of multiple structures in the vertebrate embryo. Development 126: 1211-1223.

Yokoi H, Nishimatsu A, Ozato K, Yoda K. 2003. Cloning and embryonic expression of six wnt genes in the medaka (Oryzias latipes) with special reference to expression of wnt5a in the pectoral fin buds. Development, Growth and Differentiation 45: 51-61.

Yonei-Tamura S, Abe G, Tanaka Y, Anno H, Noro M, Ide H, Aono H, Kuraishi R, Osumi N, Kuratani S, Tamura K. 2008. Competent stripes for diverse positions of limbs/fins in gnathostome embryos. Evolution \& Development 10: 737-745.

Received: 28 October 2013

Revised and accepted: 10 July 2015

Published online: 10 December 2015

Editor: A. Minelli 